\title{
Books and publishing in a digital age - an introduction
}

Hjarvard, Stig; Helles, Rasmus

Published in:

Northern Lights. Film \&amp; Media Studies Yearbook

DOI:

10.1386/nl.13.1.3 7

Publication date:

2015

Document version

Early version, also known as pre-print

Document license:

CC BY-NC-ND

Citation for published version (APA):

Hjarvard, S., \& Helles, R. (2015). Books and publishing in a digital age - an introduction. Northern Lights. Film \&amp; Media Studies Yearbook, 13(1), 3-9. https://doi.org/10.1386/nl.13.1.3_7 


\title{
Books and publishing in a digital age - An introduction
}

\author{
Stig Hjarvard and Rasmus Helles \\ University of Copenhagen
}

\section{Suggested citation}

Hjarvard, S. and Helles, R. (2014), 'Books and publishing in a digital age An introduction’, Northern Lights 13, 1, pp. 3-9, doi: 10.1386/nl.13.3_7

The book is one of the oldest media still in use, and throughout its history it has remained a central medium in western culture. Yet, within the discipline of media studies, the study of the book as a medium has never been a central issue. With a few notable exceptions (e.g. Collins 2010), it has mainly been left to historians of media (Eisenstein 1983), literary sociology (Escarpit 1970) and marketing and publishing studies (Squires 2009) to examine the technological, aesthetical and institutional transformations and characteristics of the book. Substantial contributions have been made in these disciplines and research fields, but also within these research traditions the study of the book as a medium has not been central for the disciplines and fields as such. Book history is evidently a very small research topic in the history discipline, and literary sociology is most often an adjunct to what is considered the real issue, the study of literary artworks.

During the last decade there has been renewed interest in the study of the book as a medium in several research disciplines and fields, including media studies. Current transformations of the book, including the digitalization and growing marketization of the book, seem to have pushed the old medium higher on the agenda, both within research communities and in the wider public realm. Strong dystopian or utopian views often follow when a medium is subject to significant change, and this is evidently the case with the book as well. Proponents of the printed book have announced 'the death of the book', while advocates of a new order have talked about the 'liberation of the reader', who may now access an unprecedented number of books on a global scale with the simple click of a button. Such dramatic claims usually turn out to be wrong or at best simplified and highly overstated and they may better be understood as a mixture of widespread cultural fears and hopes related to technological development and discourses of vested interests promoted by stakeholders in old and new industries. 
Irrespective of the misleading hype about the future of the book it is evident that the medium of the book is undergoing important transformations. The digitalization of the book involves all steps in the chain, from production to consumption, including the way publishers handle production and distribution, expansion of the aesthetic options available to authors, and the way consumers buy and read books. Digitalization is not an entirely new phenomenon, but was gradually implemented from the 1980s onwards - for instance, in the writing of books on personal computers and in other parts of the management of publishing and distribution (Thompson 2005, 2010). A central development during the last decade has been the spread of portable reading devices, including both dedicated e-book readers and general tablets and smartphones. These devices have opened up the last steps in the book's production cycle (the distribution and reading of the book) to digitalization. Furthermore, the global spread of the Internet has created a new context for the production, distribution and use of all analogue media and is also now changing the culture and business of books. For instance, established business models of traditional publishing houses have come under pressure, and policy-makers have begun to reconsider the regulation of book markets and copyright legislation in view of the growing dominance of global players like Google and Amazon. Similarly, the changing role of libraries in a digital environment provides a new context for the economics and distribution of the book.

Traditionally, the book as a medium has been influenced by the literary institution (defining the book as an artistic and cultural artefact) and the educational institution (defining the book as the preferred medium for learning and enlightenment), which in both cases have impacted the ways in which books have been published, distributed and read. A third factor is the influence from the larger market of popular media culture, which has influenced book publishing and reading patterns through the cultivation of popular taste - often in direct opposition to literary and educational aspirations. The balance between these three factors, which has shifted historically and varies between the various types of books and literature, has often been summarized as the contradiction between 'cathedral and market'. With the growing technological, institutional and aesthetic convergence between the book and other media, the book is now becoming more integrated into a global and digital media culture. To what extent and in what ways this will move the book further towards the market at the expense of literary and educational value is a complex question, which may not be answered at a general level, but needs to be contextualized within particular cultural and social contexts. There is no doubt, however, that several of the global newcomers to the business of books, not least Amazon, take a distinctly commercial view on books (Stone 2013).

From the point of view of existing stakeholders of the book, changes are to a large extent brought about by external developments. Global media players like Google, Amazon and Apple have introduced new forms of libraries, bookstores and business models, and public libraries are undergoing significant 
developments transforming themselves from book archives to information service providers. Digital media open up new aesthetic possibilities of multimodal books and allow readers to interact with the text. The web and social media allow readers to publish and share works of their own, enable book readers to review and criticize literature and thereby bypass traditional cultural gatekeepers like literary reviewers. In the Anglo-American world of publishing, significant changes are already manifest (Thompson 2005, 2010), while changes in the European and Nordic countries have until recently been small. This may in part be due to the particularities of the individual national book markets that stem from public regulation, industry structure, and size of national languages. Lately, however, digitalization and other changes are also beginning to have an impact in European and Nordic book markets (Hjarvard and Helles 2013; Wischenbart 2014), and this calls for particular attention to these countries.

With this volume of Northern Lights about 'Books and publishing in a digital age' we wish to strengthen research on the ongoing transformations of the medium of the book in terms of technology, industry, aesthetics and culture. In order to examine the interconnections between these various dimensions, we bring together perspectives from several research fields, in particular media studies, publishing studies and literary sociology. The contributions in this volume fall roughly within two thematic areas. In the first part we have a series of articles dealing with the changing technological and industrial context of book publishing - in particular, digitalization of the industry, the emergence of e-books and audiobooks, and the influence of open access policies. In the second part of the volume the contributions focus on the transformations of the book medium itself - that is, how texts and literary aesthetics are influenced by new technologies and how authorship and reading of books are culturally changed.

\section{The changing context of book publishing}

The volume begins with Ann Steiner's article 'Selling books and digital files: A comparative study of the sales of books and e-books in Sweden'. Using a historical approach, Steiner compares the present day's spread of the e-book in the Swedish book market to other significant structural changes in trade book publishing: the growth of subscription book clubs in the 1970s and the expansion of Internet bookshops after 1995. In view of these comparisons the impact of the e-book on the trade book market may be less disruptive and allencompassing than expected, and developments may to some extent follow similar patterns as those found in the two historical cases. Changes concern not least an increased pressure on the price of books, shifts in the market share of different kinds of sales channels, and a wider range of books available in English. There are, however, also some differences, visible for instance in the growth of self-published titles, and the rising sales of particular genres. In addition to this comes the general problem of getting readers to pay for books, since the 'free' availability of many books and other cultural products on the 
Internet - also through public libraries - puts an unprecedented pressure on the pricing of books. Ann Steiner emphasizes the need to take national conditions into account when analysing the influence of digitalization at the same time as we need to take into consideration how global developments are also affecting national markets.

The influence of the e-book on the general patterns of publishing in Sweden is also the theme of the article 'The tension of e-book creation and distribution in a small-language culture' by Skans Kersti Nilsson, Elena Maceviciute, Tom Wilson, Annika Bergström and Lars Höglund. Their analysis is focused on the perceptions of the e-book among two prominent stakeholders: the authors and the publishers. Among authors of fiction published by traditional publishers the general attitude is that they see themselves as writers of paper books, and the e-book is primarily thought of as a by-product at par with audiobooks. Among authors who are already involved in selfpublishing there is a notably different approach to the e-book. This group of authors emphasizes the possibility of reaching a larger audience and some of them are personally interested in the technological aspects of book production and distribution. Digital publishing and particularly self-publication afford the possibility of an increased interaction between authors and readers, but this affordance is not perceived as important; self-publication is primarily done in order to spread the book, not to engage in dialogue. The established publishers also display a somewhat conservative attitude towards the e-book at the same time as they recognize the significance of public libraries as an important distribution channel for e-books and consider self-publishing as a help to identify new authors. Generally, this study discerns ambivalence towards the e-book and digital self-publishing, which may also reflect the fact that Sweden is only at the beginning of the digitalization of this industry. The announcement of a new self-publishing channel for both print and e-books by the large publishing and media house Bonnier in 2014 is interpreted as an indication of a significant shift in the industry towards digital developments.

The article by Stig Hjarvard and Rasmus Helles 'Going digital: Changing the game of Danish publishing' is also concerned with the perceptions of change by key industry stakeholders. Through interviews with established publishers and bookstores as well as new actors in the field of digital book distribution and subscription services the study documents how perceptions of ongoing changes in general and of the e-book in particular differ according to the stakeholders' previous experiences and position in the market. Using the notion of 'institutional entrepreneurs' from institutional theory it becomes apparent how the hiring of professionals from outside the traditional publishing industry (for instance telecommunications, music industry, etc.) comes to influence perceptions and practices of newcomers to the business, while established publishers and bookstores subscribe to the professional norms developed inside the traditional publishing circuit, emphasizing the importance of editorial work and literary quality. Borrowing the distinction between greenfield and brownfield development from technological innovation management literature, the article highlights how perceptions are also 
influenced by the degree to which actors need to balance possible earnings in new digital businesses against possible losses in existing paper-based businesses. In conclusion, the article presents a typology of actors' orientations towards the e-book and digital change based on two intersecting criteria: the actors' relative position along the cathedral-market scale and the greenfieldbrownfield scale.

Casey Brienza's article 'Publishing between profit and public value: Academic books and open access policies in the United Kingdom' highlights dilemmas in a particular book market that has been subject to digitalization at an early stage. The open access movement has clearly had an impact on academic publishing and the activities of academic publishing houses. The scholarly research and public debate on the topic have mostly concerned the problems and opportunities of journal publishing, but in this article Brienza focuses on the consequences of open access policies on academic monographs and higher education textbooks in the United Kingdom in which the world's largest academic press, the Oxford University Press, and the world's largest higher education textbook publisher, Pearson, are located. Open access is commonly understood as the unrestricted online availability of peer-reviewed academic research, but in spite of the ideal aspirations of this policy it may have unintended consequences for both scholars, universities and the broader public. Universities that offer green open access repositories are becoming publishing houses in their own right and are increasingly seen as competitors by the commercial publishing houses. Higher education textbook publishers begin to search for new commercial ways of making use of open access resources: when content is given away freely, publishers may seek to add value through the packaging, delivering and management of such content. The spread of massive open online courses (MOOCs) may be seen as an example of this tendency and it remains a complicated question who owns the copyright to such online material. In conclusion, Casey Brienza warns that there is a real risk of concentrating control of academic book publishing within a few powerful institutions, such as affluent elite universities and large higher education publishing houses whose profits rely upon the repackaging of information made freely available through open access policies.

The last article in this section is written by Terje Colbjørnsen and concerns the e-book's aural counterpart, the audiobook: 'The accidental avant-garde: Audiobook technologies and publishing strategies from cassette tapes to online streaming services'. Informed by theories of innovation and diffusion of technology, Terje Colbjørnsen provides a detailed analysis of the innovations, successes and failures of the audiobook since the cassette deck player of the 1970s. Despite the limited market share for audiobooks there has not been a lack of innovation, which is reflected in the numerous platforms and formats launched in the 1990s and 2000s. Audiobook publishing has lived on the margins of the general publishing industry and has often been associated with a market for people with reading deficits (the visually impaired, children, etc.). Developments in audiobook technology have gradually changed this and made listening to books a more widespread 'reading' experience for 
people 'on the go'. Innovations have primarily been concerned with the platforms for playback of audiobooks, whereas little has been done as regards the content and experience. Many affordances of the digital audiobook (e.g., locative experiences through GPS and integration with other digital content) are still waiting to be utilized, but book publishers may still learn from the audiobook experiences when trying to create a robust e-book market.

\section{Transforming the book}

In her article 'The (be)coming of the book: The transformation of a text medium in the late age of print' Sara Leckner notes how digitalization has challenged our conceptual understanding of the book - both in its digital and in its analogue form - and concludes that the concept of genre can play an important role in defining the concept of the book in the digital age. She interviews prominent researchers working on e-books, in order to develop a more nuanced understanding of how the different genres will fit the e-book format. Her investigation points to the conclusion that, while all book genres can conceivably be transferred to the e-book platform, the fit will be determined by the degree to which genres depend on features specific to the printed book. We should therefore expect the transition from printed books to e-books to be gradual and to happen in different tempi for different genres, just as the genres themselves may change during the transition phase, in part as a reflection of the digitalization process.

The new possibilities offered by digital distribution formats are also central to Tore Rye Andersen's article “"Black Box” in flux: Locating the literary work between media'. In the article, Andersen analyses the ways in which Jennifer Egan's novel 'Black Box' (2012), which was distributed as a series of tweets on the New Yorkers Twitter account, utilizes the formal constraints offered by the short message format on Twitter, and argues that once literature moves away from the classical format of the printed book our analytical strategies need to change in order to accommodate the new formal strategies as well as the possibilities for reading that follow. Andersen locates the serialization of fictional novels in smaller installments as part of a historical context that includes, among others, Dickens. He also locates (fiction) writing in a larger theoretical tradition of studying the interplay of media and generic forms of texts, including perspectives from McLuhan, Hayles and Kittler. Andersen argues that John Bryant's concept of 'the fluid text' forms a relevant starting point for understanding the changes to the literary work that follows from new distribution formats.

The question of changed distribution practices and formats is also central to Sarah Mygind's article, 'McSweeney's and the act of framing: The digital excerpt between work and marketing'. She engages with the proliferation of new literary formats that follow in the wake of the digitalization of the book. The article gives a detailed discussion of an app from the literary publishing house McSweeney's, which offers access to a variety of short fiction, excerpts 
and literary news. The content, which is updated on a regular basis, provides texts that on the one hand promote the publisher's ordinary publications, but on the other hand also manifest a constantly changing universe of texts that can serve as a starting point for literary experiences in their own right. The article discusses the status of these textual fragments and argues for the usefulness of Derrida's notion of the frame as the basis for conceptualizing these textual formations, and links them to similar phenomena such as the extra material that accompanies movies released on DVDs.

The final text of the volume is Toke Riis Ebbesen's 'The multiplicity of the digital textbook as design object', which is a case study into the design process behind the so-called 'iBog' (iBook), a format for educational textbooks (accessed through web browsers) developed by the Danish publisher Systime. Using perspectives from design studies, the article argues that design needs to be understood as encompassing a wider set of perspectives than the technologycentred view taken in earlier studies. Ebbesen argues that, while design does indeed involve the construction of technological artefacts, a comprehensive understanding needs to also include the development of new business models, marketing, etc. The article argues that this approach enables the analysis of the design of the iBog to include the centrality of the databases that form the basis of digital textbooks as a central element in the design process. By including more aspects in the study of design processes, Ebbesen argues, we are better able to understand how existing templates of design (e.g. from analogue book culture) continue to play a key role in the design of digital textbooks such as the iBog.

\section{References}

Collins, J. (2010), Bring on the Books for Everybody. How Literary Culture became Popular Culture, Durham: Duke University Press.

Eisenstein, E. L. (1983), The Printing Revolution in Early Modern Europe, Cambridge: Cambridge University Press.

Escarpit, R. (1970), Le littéraire et le social. Eléments pour une sociologie e la literature/'The Literary and the social: elements for a sociology of literature', Paris: Flammarion.

Hjarvard, S. and Helles, R. (2013), 'Digital books on the point of take-off? The ebook in Denmark Anno 2013’, Academic Quarter, 7, Autumn, pp. 34-50, http://www.akademiskkvarter.hum.aau.dk/pdf/vol7/2a_SHjarvardRHelles_

DigitalBooks.pdf. Accessed 24 March, 2015.

Squires, C. (2009), Marketing Literature. The Making of Contemporary Writing in Britain, Houndmills, Basingstoke: Palgrave Macmillan.

Stone, B. (2013), The Everything Store, Jeff Bezos and the Age of Amazon, New York: Little, Brown and Company.

Thompson, J. B. (2005), Books in the Digital Age: The Transformation of Academic and Higher Education Publishing in Britain and the United States, Cambridge: Polity.

_ (2010), Merchants of Culture. The Publishing Business in the Twenty-first 
Century, Cambridge: Polity.

Wischenbart, R. (2014), 'Global eBook. A report of market trends and developments', Rüdiger Wischenbart Content and Consulting, Vienna, update

Spring.

Stig Hjarvard and Rasmus Helles have asserted their right under the Copyright, Designs and Patents Act, 1988, to be identified as the authors of this work in the format that was submitted to Intellect Ltd. 